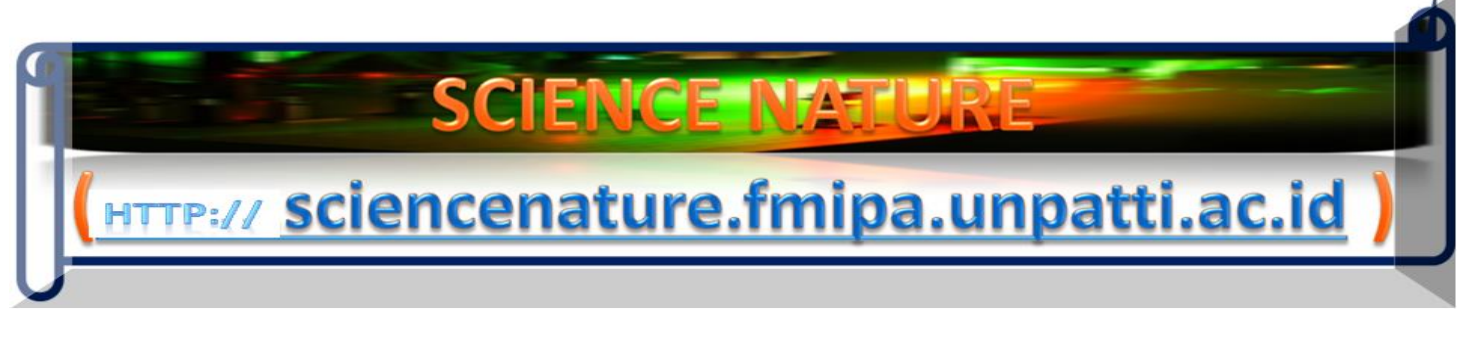

Science Nature 3(3), pp275-281 (2020)

e-ISSN: 2654-6264

DOI: https://doi.org/10.30598/SNVol3Iss3pp275-281year2020

\title{
Advancing Frontier Nanophysics in Time of Analytical Chemistry: Who to educate first?
}

\author{
Hendry Izaac Elim ${ }^{1-8, \text { a) }}$ \\ ${ }^{I}$ Nanomaterials for Photonics Nanotechnology Laboratory (N4PN Lab. ), Department of \\ Physics, Faculty of Mathematics and Natural Sciences (FMIPA), Pattimura University (UNPATTI), \\ Jl. Ir. M. Putuhena, Poka, Ambon, Indonesia 97233 \\ ${ }^{2}$ Nanotechnology Research Center and Innovative Creation (PPNRI-LPPM), \\ Research and Society Center of Pattimura University (LPPM), UNPATTI, \\ Jl. Mr. CHR. Soplanit, Rumah Tiga, Ambon, Indonesia 97234 \\ ${ }^{3}$ Multidisciplinary Research Center of Excellence (MrCE), UNPATTI, Jl. Dr. Leimena, Ambon, Indonesia 97234 \\ ${ }^{4}$ Multidisciplinary Bioinformatics Laboratory (MB Lab.), Biology Department, UNPATTI, \\ Jl. Ir. Martinus Putuhena, Poka, Ambon, Indonesia 97233 \\ ${ }^{5}$ Theoretical Physics Laboratory (TP Lab.), Department of Physics, FMIPA, UNPATTI, \\ Jl. Ir. M. Putuhena, Poka, Ambon, Indonesia 97233 \\ ${ }^{6}$ Electronics and Instrumentation Division laboratory (ELINS Lab.), Department of \\ Physics, FMIPA, UNPATTI, Jl. Ir. M. Putuhena, Poka, Ambon, Indonesia 97233 \\ ${ }^{7}$ Integrated Laboratory (I-LAB), Pattimura university, Jl. Ir. M. Putuhena, Poka, Ambon, Indonesia 97233 \\ ${ }^{8}$ Ambon Academy of Science and Arts (A-ASA), Jl. Kapitan Permata, Waitatiri, Ambon islands, Indonesia 97582
}

Received $\quad: 12^{\text {nd }}$ August 2020

Revised : $33^{\text {rd }}$ August 2020

Published : 2rd September 2020

Copyright @ All rights are reserved by Hendry Izaac Elim.

Corresponding author: *Email: : hendryelim@gmail.com; hendry.elim@staff.unpatti.ac.id 


\section{Abstract}

Frontier nanophysics in conjunction with nanomedicines, nanoscience and nanotechnology (NNN) developed before the science of analytical chemistry has been very challenges with many competitive obstacles to improve the accuracy and precise nm measurements in order to find out the point of its main chemical structure compositions, uniformity and the concentration contents to each substance. Moreover, exotics nanomaterials either in pure organic and inorganic compound or in hybrid organic-inorganics nanomaterials have shown their remarkable as well as attractive impacts in many nanotechnology and related industrial applications such as in ultrafast picosecond or femtosecond telecommunication integrated circuits and devices system, cosmetics and beauty products, as well as health or pharmaceutical drugs and herbal medicines. In this short communication paper, one explains how to educate first those who are eager indeed to study and expand their knowledge in the discovery level of understanding the nature of chemistry materials. Such guide will involve at least two to three parts of knowledge and skills consisted of the origin of life, electronics of molecular system (MES), and precise or accurate measurements. By implementing these advices, one believes the progress of applied physics frontier works in analytical chemistry will soon obtain a good harvest in the near future.

Keywords: Frontier nanophysics, analytical chemistry, chemical structure, quantitative parameter.

\section{GENERAL COMMUNICATION}

In our expanded universe with over 7 trillion galaxies in it for up to present time in the last $\sim 13.7$ billion years, the origin of life is still having unsolved mystery particularly on the unseen thing as a part of mind, spirit and soul related to matters and antimatters as well as dark matters. However, the remarkable side of current very productive ongoing multitasking researches [1-33] as illustrated in
The invented contribution: A simple concept in advancing frontier nanophysics in time of analytical chemistry was provided with general communication for wide readers in interdisciplinary fields.

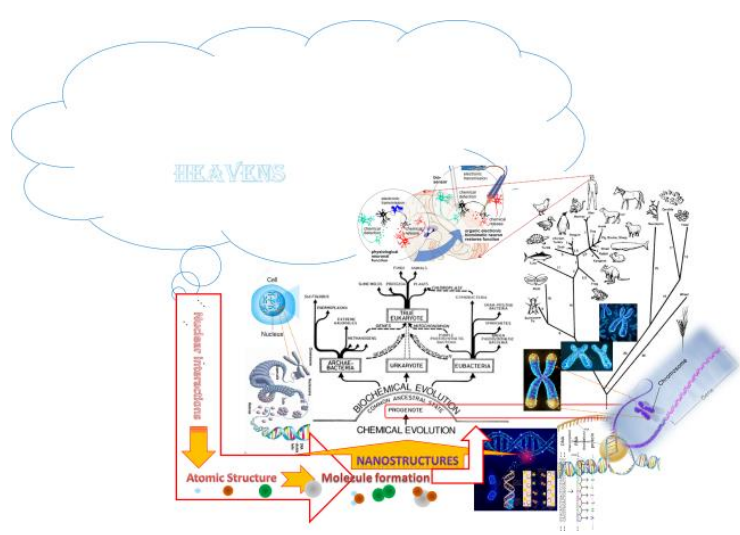

Fig. 1 that involves many different basic sciences field with the focus on multidisciplinary nanophysics studies expanded using multitasking investigations is that the core of materials which were the starting point to generate the living cell from the nuclear sizes such as boson Higgs, gluon, quarks, electron, and many other elementary particles to the basic atomic structures of $\mathrm{C}, \mathrm{O}, \mathrm{H}$, and $\mathrm{N}$ up to DNA with the size of nanometer $\left(\sim 10^{-9}\right.$ $\mathrm{m})$ has been obviously understandable with many real implementations in the development 
of the origin of organ as well as vaccines and antibodies products. Furthermore, various inventions in nanomedicines, nanoscience and nanotechnology (NNN) in the last few decades have improved the understanding in the chemistry evolution critical knowledge based on conservation of mass in conjunction with conservation of energy. In addition, the ancestor of living creatures on earth has presently clearly explained with the flowchart knowledge as embedded in Fig. 1. Therefore, it will be a challenge to analytical chemists to expand such distinguished nanophysical thought in real healthy and fruitful life of human being in this sophisticated $21^{\text {st }}$ century.

Frontier nanophysics research in analytical chemistry requires a very precise and sensitive measurement supported by an accurate theoretical physics background in nanostructure scale down to atomic interactions. Recently the use and implementation of the Gas Chromatography with a Flame Ionization Detector (GC-FID) and Gas Chromatography-Mass Spectrometry (GC-MS) apparatus duo system have been very attractive due to the high accuracy measurement of concentration quantity in each compound found in just a few liquid sample content such as essential oils, ionic liquids, and many others exotics solutions and healthy drinks. Furthermore, by incorporating the integrated measurement with the use of GC-FID and GC-MS equipment to detect the details compounds compositions in the same investigated liquids, one could analyze precisely the main compound contributions as well as its minor compounds influence to control the exact concentration quantity of it. Such creative high quality research could be supported by the origin of life knowledge [1-3,
$5,6,26]$ and the calculation by incorporating the electronics of molecular system (MES) $[16,30]$. One important question here is who to educate first?. According to our development of knowledge and understanding via spiritual belief [1], advanced philosophy [2], and theoretical physics as well as experimental implementations with social sciences in life and nanomedicines $[\mathbf{3}, \mathbf{5 - 3 3}$, the main point is on the target with a precise control [34] for those who are interested strongly to study and expand their scientific and engineering knowledge interactions in the discovery level of understanding the nature of chemistry materials. In facts, most of our research students [27-29] in the nanotechnology research center and innovative creation that we developed were significantly conducting such principles with the hope of their brighter career in the multitasking science, technology and social life.

In brief summary, the frontier nanophysics development for analytical chemistry can be improved by applying at least two to three parts of knowledge and skills in involving the investigation of origin of multi-healing system in natural products, cooperating the calculation of electronics of molecular system (MES), and measuring the precise structures of possible compound content and their each quantity concentration. We would like to suggest that the analytical chemistry for synthetic chemistry nanomaterials is hard, and it actually requires various special developed techniques to expand the advanced knowledge and understanding for gaining those aims. 


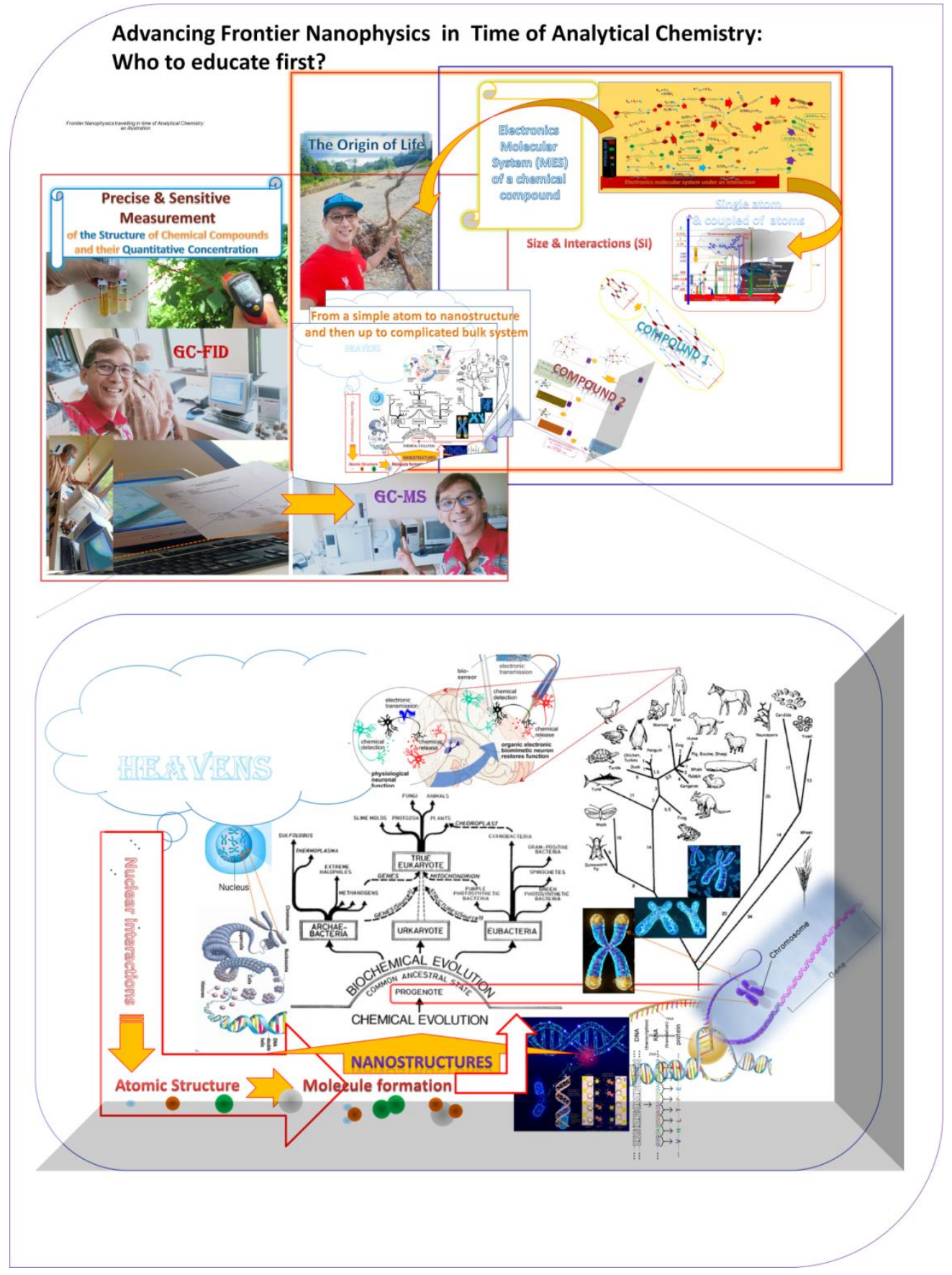

Figure 1. A scientific illustration on how to expand the frontier nanophysical works in analytical chemistry with the cooperation of two to three main parts of research investigations by focusing on those who are really eager to improve their better life with greater impacts to worldwide society. 


\section{Acknowledgment}

H.I.E. is grateful to Prof. Dr. Martinus J. Saptenno, S.H., M.Hum. for his supports in advancing science and technology at Pattimura university research center particularly in the field of nanoscience and nanotechnology as well as herbal medicine. This work has been unconditionally funded independently by using self-employed physicists in the department of physics, faculty of mathematics and natural sciences (FMIPA) at UNPATTI.

\section{References}

[1]. Electronics Holy BIBLE, Sword, for instance: the book of JOB, chapter 38 verses 1 to 41, Job 1:1,8, 2 Peter 3:5, Acts 1:11, John 6:63, 1 John 5:5-9; Ezekiel 47:12; Dan. 2:28; 4:12; Jam. 3:17-18 and Psalms 53:2-3.

[2]. H.I. Elim, E. Kembauw, R.H. Siahainenia, J.S.A. Lamerkabel, A.M. Sahusilawane, S.W. Djoko, and B. Setha, Heavenly Small Islands Simple Technology \& Its Cultural Economy Impacts in Maluku, Indonesia: a New Proposed Multitasking Philosophy in Diversity (MPD), Science Nature 2(4), pp.192-207 (2019). e-ISSN: 2654-6264 . DOI: https://doi.org/10.30598/SNVol2Iss4pp192-207year2019

[3]. M.J. Saptenno, S. Sisinaru, E. Ubwarin, W.A. Siahaya, and H.I. Elim, Customary Law Associated with Five Integrated Aspects in Developing Traditional Coastal and Marine Protections for Improving Social People Life and Natural Products in Aru Islands Region of Maluku Province, Indonesia, Science Nature 2(2), pp.105-113(2019).

DOI: https://doi.org/10.30598/SNVol2Iss2pp105-113year2019.

[4]. R.P. Feynman, There's Plenty of Room at the Bottom, Engineering and Science, Caltech, February (1960); reprinted in Hey, A.J. G., Ed., 1998, Feynman and Computation (Reading, MA; Perseus Books); reprinted in IEEE J. MEMS, p.1 (1992).

[5]. H.I. Elim, Nonlinear Optics and the Frontier of Nanoscience and Nanotechnology, Pattimura University Press, 2018. ISBN: 978-602-61906-9-7 (in English with 144 pages).
[6]. H.I. Elim, Metode fisika eksperimen: pelengkap teori fisika: "To be Perfect like The 1 Who Created Our Incredible Universe". ISBN : 978-602-5943-05-8 (in Indonesia with 155 pages).

[7]. H.I. Elim, Y.W. Zhu, and C.H. Sow, Length Dependence of Ultrafast Optical Nonlinear in Vertically Aligned Multiwalled Carbon Nanotube Films, J. Phys. Chem. C 120(31), 17733-17738 (2016).

[8]. H.I. Elim, R. Talapessy, and N.A.B.R. Sari, Water contaminated $\mathrm{CaCO}_{3}$ and its optical process of aggregation, International Journal of Health Medicine and Current Research (IJHMCR (http://www.ijhmcr.com) Vol. 1, Issue 01, pp. 102-108 (2016). DOI: 10.22301/IJHMCR.2528-3189.102

[9]. H. I. Elim, W. Ji, M.S. Dhoni, N. Venkatram, J. Yang, and J.Y. Lee, Aspect-ratio Dependence of Optical Nonlinearities on Resonance with Longitudinal Surface Plasmon in Au Nanorods: Unique Character versus Common Behavior, Science Nature Vol. 1, Issue 1, pp. 1-7 (2018).

[10]. H.I. Elim, M.V. Reddy, and R. Jose, A Frontier 2D Nanobattery: "Improving Challenges (Hotumese) and Development", Science Nature 2(2), pp. 114-121 (2019).

[11]. H.I. Elim (Elim Heaven), Ronaldo Talapessy, Rafael Martinus Osok, Sawia, and Eliyas Andreas, From Rubbish to a Large Scale Industry: A Simple Fabrication of Superfiber with Multitasking Applications, Journal of Environmental Science and Engineering B 4 (2015) 620-623.

[12]. D. Darbara, M.R. Anilkumard, V. Rajagopalanb, I. Bhattacharyac, H.I. Elim, T. Ramakrishnappaf, F.I. Ezema, R. Jose, M.V. Reddy, Studies on spinel cobaltites, $\mathrm{MCo}_{2} \mathrm{O}_{4}(\mathrm{M}=\mathrm{Mn}, \mathrm{Zn}, \mathrm{Fe}$, $\mathrm{Ni}$ and $\mathrm{Co}$ ) and their functional properties, Ceramics International 44, 4630-4639 (2018).

[13]. K.P. Abhilash, P. Christopher Selvin, B. Nalini, R. Jose, Xia Hui, H. I. Elim and M.V. Reddy, Correlation study on temperature dependent conductivity and line profile along the LLTO/LFP-C cross section for all solid-state Lithium-ion batteries, Solid State Ionics 341,115032 (2019).

[14]. H.I. Elim, A.L. Mapanawang and M.V. Reddy, A Creative Proposal to Improve Woman and Child Health: from the Knowledge of Physical Nanoscience to Nanotechnology Implementation and Products, CPQ Women and Child Health 1(6), pp. 01-11, (2019). 
[15]. H.I. Elim and L.Y. Chiang, Nanochip Medicine: Physical Chemistry Engineering, Science Nature 2(1), pp. 86-89 (2019).

[16]. H.I. Elim, Basic Universe of Molecular Electronics System (MES): Introduction and its Applications in Harvesting Daily Life, Science Nature 2(4), pp. 232-238 (2019). DOI: https://doi.org/10.30598/SNVol2Iss4pp232-238year2019

[17]. H.I. Elim, and A.L. Mapanawang, The attractive differences of two types of herbal medicine from zingiberaceae fruit (golobe halmahera), International Journal of Health Medicine and Current Research 3 (01), 799-806 (2018).

[18]. H.I. Elim, and A.L. Mapanawang, Electronics physical system of large antioxidant structure in herbal medicine based Zingiberaceae fruit: Understanding and application, $J$. Nanomed. \& Nanotech. Vol. 9, p. 65 (2018) (Abstract \& Biography).

[19]. A.L. Mapanawang, and H.I. Elim, Chemical bonding characters of love herbal medicine, J. Nanomed. \& Nanotech. Vol. 9, p. 63 (2018).

[20]. H.I. Elim, and A.L. Mapanawang, Electronics physical system of large antioxidant structure in herbal medicine based Zingiberaceae fruit: Understanding and application, Inter. J. Nano Res. \& Appl.. Vol. 1, (2018).

[21]. A.L. Mapanawang, and H.I. Elim, Chemical Bonding Character of Love Herbal Medicine: A Prominent Medicine Candidate for Preventing HIV Virus, Inter. J. Nano Res. \& Appl.. Vol. 1, pp. 1-4 (2018).

[22]. A.L. Mapanawang, and H.I. Elim, Unique Chemical Bonding Behavior of Love Herbal Medicine and Its Conjunction with Chemotherapy Drug, J. Nanomedicine and Nanotechnology 9(3), 1000503 (2018).

[23]. H.I. Elim, Physics of Multitasking Nanomedicine, IJHMCR 2 (03), 509-519 (2017).

[24]. H.I. Elim, Nanomedicine with Its Multitasking Applications: A View for Better Health, IJHMCR 2 (02), 353-357 (2017).

[25]. H.I. Elim, Scientific Breakthrough Based on Natural Creation: "1 Diamond with 7 Eyes", COJ Reviews and Research Vol. 1(1), pp.1-4 (2018).

[26]. H.I. Elim, The First 1000 Atoms in Healing Process: From Nanotechnology to Nanomedicine, International Journal of
Health Medicine and Current Research Vol. 3, Issue 04, pp.1044-1046, December, 2018.

[27]. I.F. Seay and H.I. Elim, The Observation of Fast, Long Term, and Stable Performance of Toxic Absorption in Herbal Blessing Product Based on Galoba Maluku (Zingiberaceae Fruits),

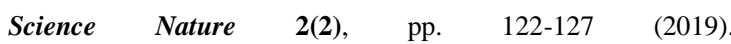
DOI: https://doi.org/10.30598/SNVol2Iss2pp114-127y2019

[28]. A. Masrikat and H.I. Elim, Unique Physical and Chemical Properties of Kian Sand Worm (Siphonosoma ur-pulau) Traditional Medicine: Electrical, Optical and Chemical Response of Edible Powder with Different Sizes, Biochemistry and Modern Applications 2(1), 51-54 (2019).

[29]. A. Masrikat, Y. Noya, and H.I. Elim, Image Processing and Optical-Electricity Property of Traditional Medicine Products from Kian Sand Worm (Siphonosoma ur-pulau), Science Nature 2(3), pp.148-156 (2019).

[30]. H.I. Elim, From Molecular Electronics System (MES) to Advanced Nanotechnology: A Progress of Frontier Development, Nano Progress 2(4), 7-11 (2020).

[31]. H.I. Elim, M. Rahman, W.S. Tutupoho, R.R. Latuconsina, A.A. Pattipeilohy, M.V. Reddy, and R. Jose, Flexible Thin Battery with Fast and Sensitive Voltage Control by a Simple Mechanical Bending: No Energy without Working, Science Nature 2(3), pp.157-166 (2019).

[32]. H.I. Elim, The Discovery of NEW Golobe and Its Amazing Healing System, Science Nature 2(1), pp.66-70 (2019). DOI: https://doi.org/10.30598/SNVol2Iss1pp066-070year2019

[33]. H.I. Elim, Multitasking Herbal Nanomedicine: A Frontier Report, Nanoscale Reports 2(1), 22-30 (2019).

[34]. H.I. Elim and G. Zhai, Control System of Multitasking Interactions between Society 5.0 and Industry 5.0: A Conceptual Introduction \& Its Applications, J. Phys.: Conf. Ser. 1463, p. 012035 (2020). 


\section{A Brief CV of Corresponding author}

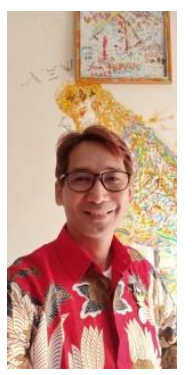

Dr. H.I. Elim is a patience scientist from Indonesia. He has developed multitasking physics research involving many different fields such as pharmacy, medical science, geoengineering and nanotechnology in the last 20 years. Based on his best achievement in such integrated field of applied physics, Prof. Elim is currently a leading scientist in Indonesia 50 best scientists overall from 400,000 Indonesia scholars.

*ORCID ID of H. I. E.: $\quad 0000-0002-4272-7115$

\section{E-ISSN: 2654-6264}

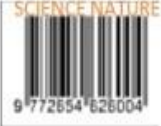

